\title{
Freddie Starr ate my privacy: OK!*
}

\author{
Robin Callender Smith ${ }^{\dagger}$ \\ PhD Candidate, Queen Mary University of London; Information Rights Judge; Media Law Barrister
}

The development of the concept of privacy in English law has been heavily influenced by the existence of two mature and specialist areas of law. Libel law has traditionally focused on reputational privacy. Equitable remedies, such as breach of confidence, have broadened to protect seclusional privacy.

These two areas of law - now developing through case law reflecting Articles 8 and 10 of the European Convention on Human Rights - are coalescing. This may lead to greater use of 'responsible journalism' techniques that address issues arising where prior notification of breaches of reputational or seclusional privacy becomes the norm.

Keywords: privacy, Article 8 ECHR, Article 10 ECHR, Max Mosley, Tugendhat J, Eady J, European Court of Human Rights

\section{INTRODUCTION}

This paper examines how privacy issues in English law and in the European Court of Human Rights in Strasbourg have matured over the last 10 years. A polarity appears to be emerging - in judicial decisions and publicly settled cases - which points up an identifiable separation into issues of seclusional privacy and reputational privacy. This reflects the pattern of the development of the law of privacy in the US from the 1890 s to the present.

If this premise is correct then it occurs some 120 years after Samuel Warren and Louis Brandeis wrote their seminal Harvard Law Review article. ${ }^{1}$ They argued that a new tort of privacy was not only necessary - given the pace of social and technological developments at the cusp of the twentieth century in US society - but that fundamental common law principles could be applied to create it.

Until the incorporation of the European Convention on Human Rights ${ }^{2}$ (ECHR) into UK domestic law in the Human Rights Act $1998^{3}$ (HRA), this creative process to define and develop a nominate tort in respect of privacy had been shunned in the United Kingdom. ${ }^{4}$

\footnotetext{
* $\quad$ Front page lead, The Sun 13 March 1986 (adapted).

$\dagger \quad$ The author's LL.B was completed at QMC in 1973. In 2010 his LL.M in Computer and Communications Law was completed at QMUL's Centre for Commercial Law Studies with Distinction and the prize for the top mark in the subject. This is an abridged and updated version of his Dissertation.

1. SD Warren and LD Brandeis, The Right to Privacy (1890) 4 Harvard LR 193.

2. Cmnd 89691950.

3. Effective 2 October 2000: Human Rights Act 1998 (Commencement No 2) Order 2000.

4. However, this did not stop English and Scots law - 40 years later - using Warren and Brandeis' precise route to create the new tort/delict of negligence in Donoghue v Stevenson [1932] AC 562.
} 
There are other echoes of Warren and Brandeis' concerns in our world today. One aspect that those authors addressed - which they tied to intrusions of privacy generally - was the ubiquitous, easy-to-use box camera (epitomized by Kodak). We now have $3 \mathrm{G}$ and $4 \mathrm{G}$ mobile telephones with still and video camera technology (complete with sound) and the ability to publish audio/visual content almost instantly.

Google and others are developing applications which will allow a picture taken of an individual at a particular GPS location to be searched against face-recognition databases for possible identities. ${ }^{5}$

Recently there have been a number of celebrities (or their friends) who have recorded specific sexual exploits or private activities using their mobile phones or used text messaging to discuss what has happened. Increasingly - with mobile telephone technology and the Internet - there seems to be an irresistible urge to share such information. The potential for these private moments to be passed on further by recipients to other friends or, directly or indirectly, to the media can be compelling. ${ }^{6} \mathrm{~A}$ casual sexual encounter with a celebrity or public figure - with (mobile) photographic or video proof that it occurred - can be worth up to $£ 250,000$ for a tabloid exclusive. ${ }^{7}$

Mr Max Mosley succeeded in his privacy action against the News of the World, ${ }^{8}$ where he recovered $£ 60,000$ damages for wrongful use and disclosure of personal information because he had a reasonable expectation of privacy. ${ }^{9}$

Yet he did not succeed in getting the video footage that formed the basis of the newspaper's stories removed from the newspaper's website between publication of the first News of the World story on 30 March 2008 and the second story on 6 April 2008. That was because, as Eady J noted: ${ }^{10}$

The evidence before me indicates that between 30 and 31 March the on-line version of the article was visited approximately 435,000 times [and] the edited footage itself was viewed about 1,424,959 times over the same period.

Eady $\mathbf{J}$ appears to have taken the pragmatic view that the cat was out of the bag and - given the ubiquitous nature of the Internet - that it had probably generated many other copies and versions. In that respect the award of only $£ 60,000$ in damages might be considered a major marketing coup for the News of the World, which has since removed the material pending the outcome of Mr Mosley's appeal to Strasbourg.

Looking further at the current development of seclusional and reputational privacy, this paper also considers the effect of the Data Protection Act 1998 (DPA) in terms of

5. Peter Fleischer, Counsel for Google, Westminster Information Group Master Class at Field Fisher Waterhouse, 22 March 2010: 'Face recognition technology is advancing at such a pace that, in searching for a face print, mobile camera shots taken by anyone on the street will soon permit immediate identification of the individual.'

6. The latest example is POI v 'Lina' [2011] EWHC $25(Q B)$ involving a Premier League player being blackmailed about a holiday encounter involving two friends and three women in Las Vegas two years ago.

7. An example is the Mail on Sunday revelations about Lord Triesman which forced his resignation as Chairman of the Football Association: <http://www.dailymail.co.uk/news/ article-1278706/FA-chief-Lord-Triesman-Spain-bid-bribe-World-Cup-referees.html>.

8. Mosley v NGN [2008] EWHC 1777 (QB) Final Judgment.

9. On 11 January 2011 the European Court of Human Rights heard his claim that UK law failed to protect Article 8 rights to privacy by not requiring newspapers and the media to notify targets of investigative journalism in advance of publication.

10. Mosley v NGN [2008] EWHC 687 (QB) Application for Interim Injunction. 
media processing of sensitive personal data and the developing situation in relation to interlocutory injunctions.

Section 32 of the DPA bears on the viability or otherwise of arguments being advanced demanding prior notification of potential breaches of privacy by Mr Mosley in Strasbourg.

Interlocutory injunctions represent the primary legal area for media targets to challenge what may or may not be said about them. This paper examines the current conflicting rules in relation to reputation and seclusion when interlocutory injunctive relief is sought. It also covers the recent development of the rules about identification of the existence of privacy injunctions and disclosure or non-disclosure of the parties involved.

As the title suggests, this paper reviews whether the excesses of the tabloid press have been responsible for the increasing deployment by celebrities of complaints about privacy. Previously their preferred weapons of choice were defamation, breach of confidence and copyright actions.

This paper also seeks to express the seclusional and reputational issues - with examples - together with the Article 8 Privacy/Article 10 Freedom of Speech issues in the context of an original diagrammatic paradigm.

\section{WHAT'S IT ALL ABOUT, ALFIE? ${ }^{11}$}

Professor Gavin Phillipson ${ }^{12}$ observed, in a keynote speech at the Westminster Legal Policy Forum:

It is now clear that we have .... a new cause of action bred from a fusion of the old action for breach of confidence with principles deriving from Article 8 ECHR protecting private life as expanded by the European Court in Strasbourg: the tort of misuse of private information, based on an unjustifiable violation of a person's reasonable expectation of privacy. ${ }^{13}$

Warren and Brandeis' exposition of the elements of the tort of privacy in the United States ${ }^{14}$ was followed 70 years later by Dean Prosser's further analysis and restatement of the tort. ${ }^{15}$ The debate about whether it could or does exist in English Law appears to have come to an end.

At times this debate has embodied the passion and commitment of the religious arguments about whether the Earth was the centre of the Universe (The Inquisition's geocentrism) or whether it was the Sun (Gallileo's heliocentrism). What is notable is the degree of denial and legal artifice - together with ingenuity - that has been necessary to fill the gaps the previous absence of this tort has engendered.

When copied engravings of Prince Albert and Queen Victoria's private sketches of themselves were about to become marketable commodities, the injunction preventing this happening - granted by the Queen's own Court of Chancery - was founded in the laws of copyright and breach of confidence. ${ }^{16}$

11. Alfie Patten was the 13-year-old putative father of Masie Stedman, the 2-month-old daughter of 15-year-old Chantelle Stedman in East Sussex CC v Stedman [2009] EWHC 943 (Fam).

12. Professor of Law, Durham University.

13. Libel \& Privacy Law - Challenges for Reform: 15 June 2010 at 61 Whitehall, London.

14. SD Warren and LD Brandeis, The Right to Privacy (1890) 4 Harvard LR 193.

15. Professor William L Prosser, Privacy (1960) California LR 48 at 383.

16. Prince Albert $v$ Strange 41 ER 1171, 1 McN \& G 2 [1849] EWHC Ch J20, (1849) 2 De Gex \& Sim 652. 
The Lord Chancellor, Lord Cottenham, concluded that Prince Albert's copyright in the sketches had been established and that an injunction was the appropriate remedy: ${ }^{17}$

In the present case, where privacy is the right invaded, the postponing of the injunction would be equivalent to denying it altogether. The interposition of this Court in these cases does not depend on any legal right; and, to be effectual, it must be immediate.

Warren and Brandeis ${ }^{18}$ specifically reflect many of the issues enunciated in Prince Albert $v$ Strange but in a way that moves things beyond the static, property rights approach to such matters. Their opening point was:

That the individual shall have full protection in person and property is a principle as old as the common law; but it has been found necessary from time to time to define anew the exact nature and extent of such protection. Political, social and economic changes entail the recognition of new rights, and the common law, in its eternal youth, grows to meet the new demands of society .... Now the right to life has come to mean the right to enjoy life, - the right to be left alone; the right to liberty secures the exercise of extensive civil privileges; and the term 'property' has grown to comprise every form of possession - intangible, as well as tangible.

They concluded: ${ }^{19}$

...the protection of society must come mainly through recognition of the rights of the individual .... The common law has always recognized a man's house as his castle, impregnable, often, even to his own officers engaged in the execution of its command. Shall the courts thus close the front entrance to constituted authority, and open wide the back door to idle or prurient curiosity?

In formulating this new tort of privacy, Warren and Brandeis took it a long way beyond the constraints of copyright, breach of confidence and other traditional remedies. It was left for State and Federal courts to adopt incorporate or ignore this exposition.

Dean Prosser noted ${ }^{20}$ that their article had little immediate effect on the law. After the principles were applied to a handful of cases in New York and Massachusetts, things came to an abrupt halt when - in 1902 - the issue reached the New York Court of Appeals ${ }^{21}$ in a case where a young woman's picture had been used without her permission to advertise flour. The court declared - in a 4:3 majority - that the right to privacy did not exist. There was no precedent for such an action; to find otherwise would open the floodgates to the "vast amount of litigation that might be expected to ensue'; there were difficulties in drawing any kind of line between public and private figures and it was also feared that to find otherwise would create undue restriction on the freedom of the press.

Prosser notes that the 30 years which followed were marked by a string of disputes about whether a right of privacy existed before - in the 1930s - 'the tide set strongly in favour of recognition and the rejecting decisions began to be over-ruled....' leaving less than five States ${ }^{22}$ rejecting and denying privacy.

17. [1849] EWHC Ch J20 (8 February 1849) 12 at [5].

18. Warren and Brandeis, The Right to Privacy.

19. Ibid at [34].

20. Prosser, Privacy, at 384 and 385.

21. Roberson v Rochester Folding Box Co (1902) 171 NY 538.

22. At the time he wrote Privacy (1960) 48 California LR at 383. 
It is clear that, even in the privacy 'homeland' of the USA, its principles were not a truth universally acknowledged. However, Dean Prosser's reformulation of the tort became the touchstone for its elements. He identified the four areas in a complex matrix of privacy issues ${ }^{23}$ as:

(1) Intrusion upon the plaintiff's seclusion or solitude, or into his private affairs.

(2) Public disclosure of embarrassing private facts about the plaintiff.

(3) Publicity which places the plaintiff in a false light in the public eye.

(4) Appropriation, for the defendant's advantage, of the plaintiff's name or likeness.'

The closest English law came to touching on any development of the law of privacy beyond Prince Albert $v$ Strange were remarks in 1894 by Lord Halsbury in Monson $v$ Tussauds Ltd where he said: ${ }^{24}$

...The exhibition in question is dedicated to the gratification of the public curiosity in regard to every person or event which may for the moment be interesting. I confess I regard such a scheme with something like dismay. Is it possible to say that everything which has once been known may be reproduced with impunity in words or pictures; every incident of a criminal or other trial be produced, and its publication justified; not only trials, but every incident which has actually happened in private life, to furnish material for the adventurous exhibitor, dramatised peraventure and justified because, in truth, such an incident had really happened?

The case itself did no more than establish 'libel by innuendo' and did nothing further to buttress privacy arguments. ${ }^{25}$

Attempts to broaden the approach of the English courts to matters relating to privacy remained intractably stuck in the traditional causes of action or failed completely. ${ }^{26}$

That is not to suggest that other areas of law - particularly breach of confidence were not pressed into service, particularly to prevent publication of kiss-and-tell tabloid material. ${ }^{27}$

In 1961 Lord Mancroft attempted unsuccessfully to introduce a Right of Privacy Bill in the House of Lords in $1961 .^{28}$ That was followed by a string of similar failed attempts by others. ${ }^{29}$

The first concerted examination of the place and position of privacy in the context of the law of the United Kingdom came from the Younger Committee Report on Privacy in $1972 .{ }^{30}$ It was a damp squib.

23. Ibid, at 388 .

24. [1894] 1 QB 671 at 687.

25. Alfred John Monson had been accused in Scotland of murder. The jury had returned a 'not proven' verdict. Madame Tussaud's Gallery in London erected a waxwork of him - at the entrance to the Chamber of Horrors - holding a gun. In the libel action he recovered one farthing.

26. Three examples spanning the period are Tolley v Fry [1931] AC 333, Bernstein of Leigh $v$ Skyview \& General [1978] 479 and Kaye v Robertson [1991 FSR 62.

27. Two examples are Stephens v Avery [1988] Ch 449 (restraint on Mail on Sunday in relation to a lesbian revelation) and Barrymore $v$ NGN [1997] FSR 606 (restraint on News of the World in respect of a homosexual relationship).

28. HL Debates Vol 229.

29. R Wacks, Personal Information: Privacy and the Law (Oxford 1989) 39-41 provides a useful overview.

30. Cmnd 5012 July 1972. 
It did recommend the creation of two new specific torts - unlawful surveillance and disclosure or other use of information unlawfully acquired - and referred to the Law Commissions of England \& Wales and Scotland the issues relating to breach of confidence with a view to clarification and restatement in statute law.

Nearly 20 years later came the report of the Committee on Privacy and Related Matters $^{31}$ chaired by David Calcutt QC. ${ }^{32}$ This report - in the author's view - arrived at a view that gentle comment and light chiding might achieve more than full-blooded, radical recommendations.

In 1992 David Calcutt QC reviewed the work of the new Press Complaints Commission. He concluded that the PCC had failed and that a privacy law was required. ${ }^{33}$ Again nothing happened save a promise from the Government that there would be a focus on improving self-regulation. ${ }^{34}$

If Alfie was still left wondering what privacy was all about, then things got no clearer in the trench warfare that could be characterised as representing the 12-year period before - and at the beginning of - the incorporation of the European Convention on Human Rights ${ }^{35}$ into UK domestic law in the Human Rights Act $1998 .{ }^{36}$

If an action - injunctive or substantive - was dressed as defamation, breach of confidence or breach of copyright then it might succeed. If it was called breach of privacy then the siege guns of the judiciary laid down crushing salvos that created sufficient collateral damage to deafen and dull the senses of Claimant and Plaintiff and those who might advise them.

The application of the Human Rights Act 1998 from 2 October 2000 did not just go to the heart of cases generated in the United Kingdom. It brought with it a gradual recognition that there had to be reciprocal reflection of the decisions by the European Court of Human Rights in Strasbourg.

A steady stream of cases - including Campbell v MGN, ${ }^{37}$ Von Hannover,${ }^{38} \operatorname{Re} S(A$ Child), ${ }^{39}$ Murray $v$ Big Pictures ${ }^{40}$ McKennitt $v$ Ash ${ }^{41}$ and others - changed the privacy landscape for ever. $S .42$

Much of this change can be attributed to the succinct analysis by Lord Steyn in $R e$

First, neither article has such precedence over the other. Secondly, where the values under the two articles are in conflict, an intense focus on the comparative importance of the specific rights being claimed in the individual case is necessary. Thirdly, the justifications for interfering with or restricting each right must be taken into account. Finally, the proportionality test must be applied to each. For convenience I will call this the ultimate balancing test.

31. Cmnd 1102 June 1990.

32. David Eady QC, as he was then, was one of the five other members.

33. Cmnd 2135 1992, Review of Press Regulation.

34. Cmnd 29181995.

35. Cmnd 89691950.

36. Effective 2 October 2000: Human Rights Act 1998 (Commencement No 2) Order 2000.

37. [2004] UKHL 22.

38. Von Hannover $v$ Germany (2005) 40 EHRR 1.

39. [2004] UKHL 47 at [17].

40. [2008] EWCA Civ 446.

41. [2006] EWCA Civ 1714.

42. Re S (A Child) Identification: Restrictions on Publication [2004] UKHL 47 at [17]. 
In practical terms the $\operatorname{Re} S$ analysis takes place in two stages. Stage 1 requires engagement of the relevant Articles and - in relation to Article 8 in this context - that requires there to be a reasonable expectation of privacy. Stage 2 is resolved when Lord Steyn's process, described above, is undertaken and concluded.

\section{MAX MOSLEY: PRIVACY AND STRASBOURG}

\section{Eady $\mathbf{J}$ described legal landscape in the Mosley case as follows: ${ }^{43}$}

Although the law of 'old-fashioned breach of confidence' has been well established for many years and derives historically from equitable principles, these have been extended in recent years under the stimulus of the Human Rights Act 1998 and the content of the Convention itself. The law now affords protection to information in respect of which there is a reasonable expectation of privacy, even in circumstances where there is no pre-existing relationship giving rise to an enforceable duty of confidence. That is because the law is concerned to prevent the violation of a citizen's autonomy, dignity and self-esteem. It is not simply a matter of 'unaccountable' judges running amok. Parliament enacted the 1998 statute which requires these values to be acknowledged and enforced by the courts. In any event, the courts had been increasingly taking them into account because of the need to interpret domestic law consistently with the United Kingdom's international obligations. It will be recalled that the United Kingdom signed up to the Convention more than 50 years ago.

Mosley is a definitive case, not least because Eady $\mathrm{J}$ launched himself on the academic and conference circuit to speak about it on three occasions since delivering the judgment, following criticism of his conclusions by the press and media. ${ }^{44}$ The facts are summarized briefly below because issues within the case are now awaiting the European Court of Human Rights' judgment (expected mid 2011).

In March and April 2008, the News of the World published a series of articles revealing that Max Mosley, President of the Federation Internationale de l'Automobile (FIA), had engaged in group, sadomasochistic sex sessions, privately with five prostitutes. One of the prostitutes hired to take part in the sessions had used a hidden camera to make a video recording of the sexual activity. ${ }^{45}$ The video accompanied the story, which was headlined ' $F 1$ boss has sick Nazi orgy with 5 hookers' and contained explicit detail and photographs of the sexual activity.

The News of the World alleged that the sexual role-play had Nazi overtones, an allegation that was found to be false at trial - a major reason why the judge concluded that the story had no public interest value. The litigation was in two stages: in the first, ${ }^{46}$ Mosley sought an interim injunction against further publication of the story and an order that the video be removed from the News of the World's website; this application was refused. At the trial of the action, however, the judge found in favour of Mosley's claim for infringement of his privacy, awarding an unprecedented $£ 60,000$ in damages.

43. Ibid, at [7].

44. University of Hertfordshire 10 November 2009, 'Justice' Conference 1 December 2009 and City University 10 March 2010.

45. As described by the judge, 'The session seems to have been devoted mainly to activities which were conveniently described as "S and M".'

46. [2008] EWHC 687 (QB). 
The theming of 'Nazi' elements remained unsubstantiated at the trial because the News of the World's key witness on this point - Woman E - who had filmed the event, failed to appear at court claiming she was 'mentally and emotionally unfit' to give evidence. No corroborating medical evidence to that effect was ever provided for the court. She was then interviewed on television and made remarks that immediately destroyed any prospect of an appeal by the paper. ${ }^{47}$

The core question is whether - to secure effective protection of Article 8 privacy rights - the domestic law of the United Kingdom should require media editors to contact the target of the story ahead of publication. Private information, which the author of this paper terms seclusional, once in the public domain can never be made private again. It is therefore important to allow the individual who is the focus of the story an opportunity to prevent its publication. It is not a situation comparable to the regime which operates in terms of defamation - in this paper termed reputational where damages are available against defendants if a claim of truth/justification at the injunctive stage subsequently fails if the matter goes to full trial.

Eady $\mathrm{J}$ highlighted that conundrum in the Mosley case: ${ }^{48}$

Whereas reputation can be vindicated by an award of damages, in the sense that the claimant can be restored to the esteem in which he was previously held, it is not possible where embarrassing personal information has been released for general publication. As the media are well aware, once privacy has been infringed, the damage is done and the embarrassment is only augmented by pursuing a court action. Claimants with the degree of resolve (and financial resources) of Mr Max Mosley are likely to be few and far between. That is, if journalists successfully avoid the grant of an interlocutory injunction they can usually relax in the knowledge that intrusive coverage of someone's sex life will carry no adverse consequences for them.

Prior notification does occur, however, even when sensitive personal information exists. When the Sunday Express decided to run the Jacqui Smith MP expenses story 49 for Sunday 29 March 2009 - including the fact that she had claimed for an 'adult' film watched on her home television - a call was made to the Home Office at $1.15 \mathrm{pm}$ on Saturday 28 March. The Home Secretary's press secretary asked for 45 minutes to respond and did so with a brief, prepared statement from the Secretary of State. This confirmed the essence of the story. The duty lawyer on the Sunday Express had a QC available to deal with any application for an emergency injunction. In the event he was not needed. The approach taken ensured that, both in terms of defamation and reputational privacy issues, the elements of the Reynolds defence were demonstrably present and - if necessary - could be argued by analogy to resist in equal measure an injunction seeking to protect the Home Secretary's (and her family's) seclusional privacy until the trial of any contested action.

This approach was specifically adopted to accommodate the 10-point checklist mentioned in the Reynolds defence. ${ }^{50}$

47. Eady J, ibid from [79 to 97], also pointed out that Neville Thurlbeck, the paper's chief reporter, blackmailed Women A and B for their contribution in the follow-up story on 6 April 2008 by threatening to publish un-pixelated pictures of them unless they cooperated with the paper.

48. At [230].

49. <http://www.express.co.uk/posts/view/91920/JACQUI-SMITH-PUT-ADULT-FILMSON-EXPENSES $>$.

50. Reynolds $v$ Times Newspapers Limited [1999] UKHL 45. 
There are two statutory brakes to injunctive action that operate in this area. First, Section 12 (3) HRA states that "no relief is to be granted so as to restrain publication before trial unless the court is satisfied that the applicant is likely to establish that publication should not be allowed'. Lord Nicholls ${ }^{51}$ interpreted 'likely to establish' as meaning 'more likely than not' (the civil 'balance of probabilities' test), installing the likelihood of winning at trial as the test for a pre-publication injunction. The burden of proof required to secure the pre-publication injunction falls squarely on the Claimant.

Secondly there is the Data Protection Act 1998 and the approach set by Parliament to journalistic publication of sensitive personal data in section 32 of that Act. Section 32 specifically focuses on the acquisition of private information, its storage, consideration, preparation and publication by media organizations. The section includes an exemption that applies to data processing for the 'special purposes' of journalism, art and literature. The substantive exemption ${ }^{52}$ absolves data controllers from the duty to adhere to most of the data protection principles if certain criteria are satisfied and this is linked to a procedural exemption.

The procedural exemption ${ }^{53}$ is engaged where proceedings are brought against a media organization in respect of personal data that are being processed with a view to publication but which have not yet been published. Such proceedings must be stayed by the court to ensure that interim injunctions cannot be obtained under the Act in order to prevent media publication, leaving the ultimate remedy in damages.

Mr Mosley's application went before the Fourth Section of the European Court of Human Rights in January 2011. The Court had also received written submissions from Geoffrey Robertson QC, Heather Rogers QC and Lord Lester QC on behalf of various media interveners.

Because the judgment is not expected for several months, the key points presented are summarized in the paraphrased text that follows. ${ }^{54}$ The Court identified three questions for the parties:

(1) Given the award of $£ 60,000$ could Mr Mosley still claim to be a victim in respect of his Article 8 complaint?

(2) Had there been a failure to protect his right to respect for his private life, contrary to Article 8 of the Convention? In particular:

(a) Did the Government have a positive obligation to protect the applicant's privacy by providing for a legal duty (a 'notification requirement') on the News of the World to warn him in advance of publication in order to allow him to seek an injunction?

(b) Would such a positive obligation and corresponding duty on newspapers and other media strike the correct balance between the interests protected under Article 8 and freedom of expression as guaranteed by Article 10 of the Convention?

(3) Are privacy damages adequate remedies for invasion of privacy and had Mr Mosley exhausted his domestic remedies?

Mr James Eadie QC, on behalf of the UK Government, submitted that the case was concerned with the 'structural balance' that had to be struck between the rights

51. In Cream Holdings Ltd v Banerjee [2004] UKHL 44 at [22].

52. DPA s 32 (1)-(3).

53. DPA s 32 (4)-(5).

54. The author is indebted to Edward Craven at Matrix Chambers for this summary: see $<$ http://inforrm.wordpress.com/2011/01/13/strasbourg-hearing-mosley-v-united-kingdomedward-craven $>$. 
protected by Article 8 and the rights protected by Article 10. Four reasons existed for the Court to afford a broad margin of appreciation to the United Kingdom:

(1) The application concerned the issue of positive obligations owed by a state under Article 8. A wider margin of appreciation was appropriate. Mr Mosley was contending that the Government was under a duty to impose obligations upon one private individual in respect of his conduct towards another private individual.

(2) There were important interests on both sides of the issue. Striking the balance between these interests involved a delicate exercise of judgment by each Contracting State. Restrictions on free expression could only be justified if a state has 'convincingly established' the necessity of such a restriction. There was a danger of the potential chilling effects of any restraint that operated pre-publication. These factors favoured a broad margin of appreciation.

(3) The judgment about where to strike the balance depended upon the history, culture and conditions of different countries.

(4) A comparative analysis demonstrated a wide diversity of approaches to the question of prior notification across different jurisdictions. This was important both (a) in establishing that a broad margin of appreciation is appropriate; and (b) in demonstrating that the United Kingdom and many other states have for many years had structures that operate satisfactorily without any system of prior notification. He referred to the fact that there is no requirement of pre-notification in France, Germany, Sweden, Hungary, the Netherlands and Belgium. Moreover the UK Government and the House of Commons Culture, Media and Sport Select Committee had both previously declined to support the introduction of a general pre-notification requirement.

He emphasized that the question was not whether a prior notification requirement would be useful or desirable solely from the perspective of Article 8. Instead, the sole question was whether such a requirement was necessary under Article 8 when set against Article 10.

He then went on to argue that UK law already afforded adequate protection to privacy rights. An individual's Article 8 rights were already protected by the cause of action of misuse of private information and if a breach of those rights was established following a trial then the court could award substantial damages, the individual could bring a claim under the Data Protection Act 1998 or pursue the matter through the Press Complaints Commission (PCC).

Lord Pannick QC, on behalf of Mr Mosley, responded by setting out six key propositions:

(1) 'Privacy once breached, cannot be restored by court order.' Maintenance of privacy vitally depends on keeping confidential material outside the public domain. Therefore the only effective remedy for an invasion of privacy was the granting of an injunction.

(2) If the applicant had known that the newspaper intended to publish a story about his sex life, he would have successfully applied for an injunction.

(3) In this case the newspaper had deliberately avoided notifying the applicant about its intention to publish details of his sex life because it wanted to prevent him from seeking and obtaining an injunction.

(4) The newspaper was well aware that once a story was published very few victims were likely to sue for breach of privacy. It took a determined and wealthy litigant to go through the ordeal of a High Court trial where embarrassing personal behaviour was 'reheated' for detailed public examination. The cost risks were great and even successful claimants often ended up out of pocket. 
(5) It followed that whether the subject of a story was able to seek and obtain an effective remedy depended upon the willingness of the newspaper to notify him in advance of publication. However, the more flagrant the breach of privacy (and therefore the stronger the prospects of obtaining an injunction), the less willing the newspaper would be to give advance notification. This meant that the party breaching privacy was also the party in the position of judging whether the protection of human rights and the administration of justice should be frustrated. In other words, 'the wrongdoer was judge in its own cause'.

(6) The newspaper's rights to free expression were fully protected by the Human Rights Act - an application for an injunction to restrain publication does not threaten these rights. No pre-publication injunction would be granted unless the court was satisfied that the applicant was likely to establish at trial that publication should be restrained. The newspaper therefore had no valid reason for seeking to prevent the court from hearing an application to protect privacy. The desire to prevent an individual from obtaining an injunction was not a valid reason for these purposes.

\section{BONNARD V PERRYMAN - A VINTAGE TO SAVOUR ... OR OLD WINE PAST ITS STRASBOURG SELL-BY DATE?}

After Mosley - on the front line of privacy injunctions - came the Terry case. Terry ${ }^{55}$ involved a thorough examination of the interrelationship between the principle that the court may grant an interim injunction to prevent a threatened misuse of private (seclusional) information on Lord Nicholls' 'more likely than not' test in Cream Holdings Ltd $v$ Banerjee ${ }^{56}$ and the rule in Bonnard v Perryman ${ }^{57}$ which created an equal and opposite principle that interim injunctions in defamation (reputational) cases will not be granted if the truth of what is to be stated will be relied on by the Defendant at full trial of the action.

It fell to Tugendhat $\mathrm{J}$ to identify the conundrum in $R S T v U V W{ }^{58} \mathrm{He}$ concluded:

At some point, the court will have to grapple again with the question of where the principle of Bonnard v Perryman applies, and where it does not, when an application is made on the basis of privacy, but it is an application to restrain publication of material which is arguably defamatory. The court will have to decide how the rule .... is to be applied in the light of such authorities as are then available as to the status of reputation as an Article 8 right and, if it is an Article 8 right, how the exercise the ultimate balancing test referred to in $\operatorname{Re} S$ is to be applied on an interlocutory application....

Four months later the Terry case came before him on just this point. It involved John Terry, Captain of Chelsea FC and - at the time - the England football team. As a married man, he applied for an interim injunction - without giving prior notice to any Respondent - seeking to prohibit 'persons unknown' from publishing 'information or purported information' in relation to four specified areas:

(1) The fact that he had an intimate personal relationship with a woman who was not his wife (who was, as it turned out, Vanessa Perroncel (VP)) who was the ex-girlfriend of an England and former Chelsea FC team mate.

55. [2010] EWHC $119(\mathrm{QB})$.

56. [2004] UKHL 44 at [22].

57. [1891] 2 Ch 269 (CA).

58. [2009] EWHC 2448 (QB). 
(2) Details of that relationship including the fact that VP had become pregnant and that he had contributed to the cost of the terminating the pregnancy.

(3) Information that would lead to either of them being identified.

(4) Photographs relating to such matters.

Tugendhat $\mathbf{J}$ heard the application on 22 January 2010 , granted a temporary injunction pending his decision, and a week later refused to continue the interim injunction, noting ${ }^{59}$ that John Terry accepted the truth of some of the information. He set out his reasons in eight specific points. 60

He decided (as per Buxton $\mathrm{J}$ in McKennitt $v A s h^{61}$ ) that the claim was a reputational claim in defamation and not a seclusional claim - as it had been presented - rooted in breach of confidence and private information. As such he regarded himself as bound by the rule in Bonnard v Perryman, affirmed in Greene v Associated Newspapers. ${ }^{62}$

$\mathrm{He}$ addressed a series of factual scenarios, having noted that it is only in limited classes of cases that the law of privacy gives rise to an overlap with the law of defamation' and identified four groups of cases:

(1) Cases where there is clearly no overlap and where the information could not be said to be defamatory such as Douglas $v$ Hello! ${ }^{63}$ and Murray. ${ }^{64}$

(2) Cases where there is an overlap but where it was unlikely that it could be said that protection of reputation forms the nub of the claim. These included cases where information would in the past have been said to be defamatory even though it related to matters, like disease, which were involuntary.

(3) A third group of cases contained an overlap but no inconsistency. The information in this group related to conduct which was voluntary and said to be seriously unlawful even if it was personal in a sexual or financial sense. In this group of cases the Claimant was unlikely to succeed whether at an interim application or - if the allegation was proved - at trial, irrespective of whether it was under the law of defamation or the law of privacy.

(4) The final group was where information related to conduct which was voluntary, discreditable and personal in a sexual or financial sense but was not unlawful (or not seriously so). In defamation, if the defendant succeeded in one of the libel defences he would not have to establish any public interest (unless Reynolds privilege was being relied on). If it was the Claimant's choice alone that determined that the only course of action which the court could take into account was misuse of private information, then the defendant could not succeed unless he established that it came within the public interest exception.

Godwin Busuttil and Patrick McCafferty ${ }^{65}$ have considered the effects of grouping the cases this way - together with the associated issues - and highlight the dangers in adopting Tugendhat J's approach. They note: ${ }^{66}$

The focus of the court in Terry on the question of what the claim was 'really' about - misuse of private information or protection of reputation - with a view to determining which set of rules governing the grant or refusal of interim injunctive relief was applicable, appears to us

59. Ibid at [6].

60. Ibid at [149].

61. [2006] EWCA Civ 1714.

62. [2004] EWCA Civ 1462.

63. [2007] UKHL 21.

64. [2008] EWCA Civ 446.

65. Barristers at 5RB.

66. 'Interim Injunctions and the Overlap between Privacy and Libel' [2010] 2 (1) Journal of Media Law $1-13$ at 8 [2]. 
to be unsatisfactory. It places a premium on specialist knowledge and clever drafting: whether an applicant can formulate the evidence in the right way to get the desired result. It also seems to us to invite judicial idiosyncrasy - the question of which set of rules prevails being dependent upon whether the particular judge hearing the application is disposed to take the claim at face value or look beneath the surface - and as such is a recipe for uncertainty. This does not seem desirable in the interests of justice.

They question whether Greene ${ }^{67}$ can remain good law. Although Tugendhat $\mathrm{J}$ regarded himself as bound by it in its reaffirmation of Bonnard v Perryman (particularly in cases involving private, seclusional information relating to individuals) they set out six reasons to support their view. ${ }^{68}$

Given the critical importance of this interlocutory battleground in the developing case law of matters relating to the seclusional and reputational privacy - where to win or to lose in many cases determines the outcome (or even existence) of any future trial - Busuttil and McCafferty's analysis of potential solutions and future outcomes in this area is timely.

They conclude: 'The rule in Bonnard v Perryman is not a jurisprudential sacred cow that needs to be culled, ${ }^{69}$ but it seems reasonably clear that certain parts of it need to be sacrificed. ${ }^{70}$

They propose that if the information is recognizably seclusional in terms of engaging a claimant's Article 8 right to respect for private life (regardless of whether it is also true, false, defamatory or otherwise) or is reputational to the extent that it engages a claimant's Article 8 right to protection of reputation as an aspect of the right to respect for private life ${ }^{71}$ then the test for the grant or refusal of interim injunctive relief should be that provided in section 12 (3) HRA as interpreted by the House of Lords in Cream Holdings Ltd $v$ Banerjee.

They do not think their suggestion would be a charter for more injunctions. They argue that if the new rule were adopted then truth would remain as an important factor in cases where the information at issue is defamatory in respect of the applicant. ${ }^{72}$

The battle then shifted to whether - in seeking a privacy injunction - the fact that it was being sought at all (by whom and against whom) should be made public. In the 'super-injunctions' arena, two cases stand out in this latest area of the development of the law of privacy.

JIH $v$ News Group Newspapers ${ }^{73}$ is a decision of Tugendhat $\mathrm{J}$ that went to the Court of Appeal in January 2011 and on which judgment is awaited. Tugendhat $\mathbf{J}$ had decided that issues relating to JIH's private life were engaged and there was no suggestion of any public interest in disclosure of the information. But he ruled that $\mathrm{JIH}$ had not shown to the necessary high standard that the object of achieving justice in the case would be rendered doubtful if the anonymity order were not made.

\section{7. [2004] EWCA Civ 1462.}

68. 'Interim Injunctions and the Overlap between Privacy and Libel' at 8-10.

69. In the sense contemplated by the House of Lords in $R v$ Lambert [2002] $2 \mathrm{HC} 545$ at [6].

70. Interim Injunctions and the Overlap between Privacy and Libel' at 12.

71. As per the Supreme Court decision In re Guardian News and Media Ltd \& Others [2010] UKSC 1 . The authors recognize that this may define too widely a category of defamatory information to which s 12 (3) HRA ought to apply. They accept that the category could be confined to defamatory information - sexual or financial - which is private in character and whose publication would be intrusive.

72. 'Interim Injunctions and the Overlap between Privacy and Libel'at 13.

73. [2010] EWHC 2979 QB. 
He said that it was not possible 'to do perfect justice to all parties and to the public at the same time', but an order which identified JIH but kept information about the subject matter confidential would be effective to achieve justice and give all necessary protection to the private lives of those concerned. ${ }^{74}$

The Court of Appeal, in Adakini Ntuli v Howard Donald, ${ }^{75}$ in November 2010 lifted an anonymity order and publicity ban granted to a pop star to stop a former girlfriend selling her story about their relationship. The media were free to identify Take That band member Howard Donald as the claimant, and report the fact that he had obtained an injunction, but the court kept in place an order banning singer Adakini Ntuli from publicizing what had happened during their nine-year relationship.

\section{THE SECLUSIONAL/REPUTATIONAL PARADIGM}

\section{Hugh Tomlinson QC observed: ${ }^{76}$}

$\ldots$ the inevitable result of the recognition of an Article 8 right to reputation is to blur the boundaries between privacy and defamation and to require 'case by case' assessment of the balance between expression and reputation. The implications of a 'Convention right to reputation' are potentially far-reaching for English defamation law. In the long term, the boundary between 'privacy' and 'defamation' cases may disappear, leaving a 'continuum' of Article 8 cases.

What follows is an attempt to express those thoughts diagrammatically. The east/west axis places seclusional privacy (in terms of pictures, videos and private, personal matters) to the left. Reputational privacy (in terms of a person's good name, honesty, lack of hypocrisy) is on the right.

The north/south axis reflects the tension between Article 8 private life issues at the bottom and Article 10 freedom of speech issues at the top.

Cases above the horizontal axis are those where publication has been permitted (at least in part) or not challenged. Cases below that axis indicate that Article 8 privacy issues have predominated to prevent publication or have resulted in awards of damages or settlements.

To give an idea of the practical operation of this paradigm, the following representative cases could be placed as follows:

1 Top left quadrant: $B K M \vee B B C^{77}$ (no breach of Article 8 to show elderly patients in television documentary); Stedman; ${ }^{78}$ Sarah Ferguson ( $£ 500,000$ 'cash for access' to Prince Andrew in News of the World undercover video interview) ${ }^{79}$ and Lord Treisman. ${ }^{80}$

74. Almost immediately contempt proceedings were considered by Tugendhat $\mathrm{J}$ on 12 November 2010 against the Daily Telegraph and another newspaper. They had inadvertently breached the terms of the original order and their apologies were accepted.

75. [2010] EWCA Civ 1276: an appeal against a decision by Eady J allowing Howard Donald initial anonymity.

76. <http://inforrm.wordpress.com/2010/03/15/strasbourg-reputation-and-privacy-part-3-abalance-between-reputation-and-expression>.

77. [2009] EWHC 3151 (Ch).

78. East Sussex CC v Stedman [2009] EWHC 943 (Fam).

79. <http://www.newsoftheworld.co.uk/news/822206/Duchess-of-York-Sarah-Fergusonplots-to-sell-access-to-Prince-Andrew.html>.

80. <http://www.dailymail.co.uk/news/article-1278706/FA-chief-Lord-Triesman-Spain-bidbribe-World-Cup-referees.html $>$. 


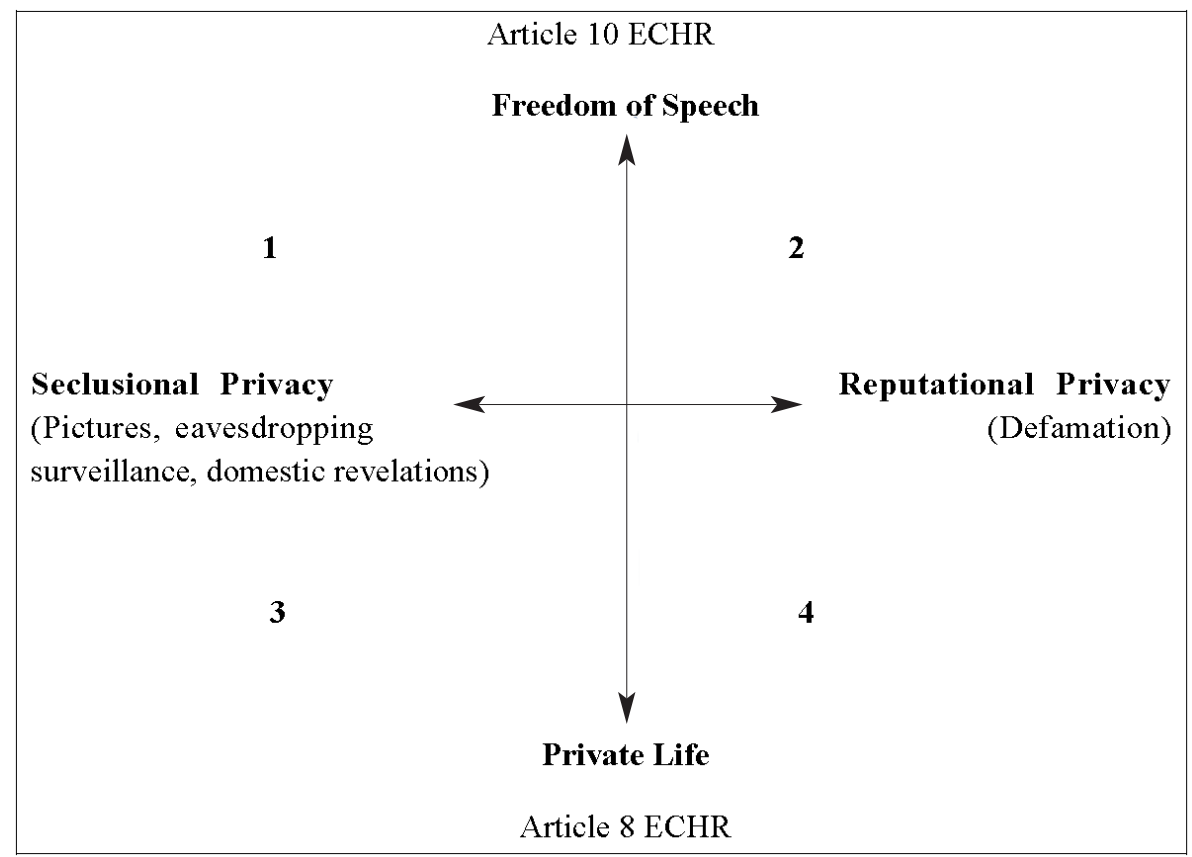

\section{Outline Privacy/Free Speech Paradigm}

2 Top right quadrant: Terry $;{ }^{81} B B C v A G$ reference No 3 (television documentary permitted on man acquitted of a rape when DNA evidence was incorrectly excluded at his trial); ${ }^{82}$ Browne $v$ Associated Newspapers (homosexual revelation permitted, particularly given circumstances of denial evidence); ${ }^{83}$ Greene $v$ Associated Newspapers $;{ }^{84}$ Theakston $v$ MGN (text of events in brothel permitted but pictures barred); ${ }^{85}$ Eldrick Tont (Tiger) Woods $v X \&$ $Y$ (2010); the Jacqui Smith expenses story. ${ }^{86}$

3 Bottom left quadrant: Campbell v MGN; $;{ }^{87}$ Von Hannover ${ }^{88}$ Murray v Big Pictures $;{ }^{89}$ Douglas $v$ Hello ${ }^{90} X \vee B B C$ (written participation agreement in television documentary did

81. [2010] EWHC 119 (QB).

82. [2009] UKHL 34.

83. [2007] EWCA Civ 295.

84. [2004] EWCA Civ 1462.

85. [2002] EWHC 137(QB).

86. <http://www.express.co.uk/posts/view/91920/JACQUI-SMITH-PUT-ADULT-FILMS-

ON-EXPENSES $>$..

87. [2004] UKHL 22.

88. (2005) 40 EHRR 1.

89. [2008] EWCA Civ 446. There was a detailed first instance examination of all the issues by Patten J in [2007] EWHC 1908 (Ch), some of which might have prevailed in the House of Lords if Big Pictures had pursued the appeal further. Express Newspapers, sued as the First Defendant, settled the matter almost immediately with a payment of $£ 500$ to the 18 -month-old Claimant's litigation friends (his parents JK Rowling and her husband) and were released from the escalating costs of the action at an early stage.

90. [2007] UKHL 21. 
not mean BBC could broadcast material showing Appellant intoxicated and with apparent mental health problems in an area close to court) ${ }^{91}$ Peck $v$ UK $;{ }^{92}$ Prince of Wales $v$ Associated Newspapers $;{ }^{93} R$ (Wood) $v$ Metropolitan Police Commissioner $;{ }^{94}$ Kate Middleton (Christmas tennis: $£ 10,000$ settlement from Rex Features on pictures taken); 95 Avram Grant (football manager leaving brothel: pictures banned but text allowed); ${ }^{96} \mathrm{Kai}$ Rooney ( $£ 10,000$ settlement and apology by Sunday Express when 5-month-old was pictured in Colleen Rooney's arms at Aintree Grand National 2009 when mother had been paid a $£ 50,000$ celebrity attendance fee); ${ }^{97}$ Jude Law ( $£ 9,500$ settlement with Hello! magazine $^{98}$ and permanent injunction from Tugendhat J preventing his ex-wife Sadie Frost using pictures of their children in her autobiography) ${ }^{99}$ and Matt Lucas (who recovered undisclosed damages for breach of privacy when the Daily Star suggested he was on suicide watch and had found a new boyfriend following the suicide of his former civil partner Kevin McGee). ${ }^{100}$

4 Bottom right quadrant: Mosley; ${ }^{101}$ McKennit v Ash $;{ }^{102}$ RST v UVW ${ }^{103}$ and Karako v Hungary. ${ }^{104}$

The diagram allows distinctions between what is published in textual form - as in Theakston, Mosley and Avram Grant situations - and the separate use of pictures or (Web-linked) video material on newspaper or television websites. This latter area is likely to become increasingly significant because of the increase in joint newspaper and television ownership in the UK, the EEA and across the world.

Most newspaper titles have a Web presence and many feature video material that is linked to or derived from pictures used with newspaper copy. Often the photograph is a still 'video grab' taken from a much greater body of material.

There are two continuing issues for the future that will nearly always require decisions which are fact-based and which may not read across into more general principles.

One area is stories involving pictures, sound and video material which impinges on or infringes an individual's seclusional privacy. ${ }^{105}$ The other is the extent to which

91. [2005] SCLR 740.

92. (2003) 36 EHRR 41.

93. [2006] EWNC $522 \mathrm{Ch}$.

94. [2009] EWCA Civ 414.

95. <http://www.guardian.co.uk/media/greenslade/2010/mar/11/privacy-news-agencies $>$.

96. <http://www.telegraph.co.uk/sport/football/news/7151797/Avram-Grant-PremierLeague-bosss-brothel-visit.html>.

97. Unreported.

98. <http://www.guardian.co.uk/media/2010/apr/08/hello-jude-law-privacy-damages >.

99. <http://www.guardian.co.uk/media/2010/jul/06/jude-law-sadie-frost-autobiography>.

100. <http://www.medialawyer.press.net/article.jsp?id=6794571>.

101. [2008] EWHC 1777 (QB).

102. [2006] EWCA Civ 1714.

103. [2009] EWHC 2448 (QB).

104. Application 39311/06 ECHR: Heather Rogers QC has pointed out that 'integrity' and 'reputation' are different attributes, a point overlooked by the UK Supreme Court in its 2010 Guardian decision.

105. A second Von Hannover v Germany case (no. 40660/08) was heard on 13 October 2010 before the 17-member panel of the ECHR. Princess Caroline of Monaco complained about the publication of three photographs in the magazines Frau im Spiegel - showing her and her husband on skiing holidays. The German Federal Constitutional Court (Bundesverfassungsgericht) had rejected her claims on the basis that her Article 8 rights had to give way to the fundamental rights of the press (1 BvR 1626/07). The judgment is awaited. 
reputational privacy is (or is not) protected from any linkage to pictures, video or audible material.

These two issues coalesced in the photographic 'protection' - on the purported grounds of privacy and security - given to Naomi Campbell at the Special Court for Sierra Leone's (SCSL) hearings in The Hague. ${ }^{106}$ These related to whether she did or did not accept a gift of 'blood diamonds' from former President Charles Taylor of Liberia.

Because there was a live video-link feed of her evidence at the SCSL, what she actually said, how she said it and how she looked were all rapidly available on the Web. ${ }^{107}$

The SCSL's decision was a remarkable one, not least because no representations were invited from the press or media before the three judges delivered their decision on 3 August 2010, two days before Ms Campbell gave her evidence. ${ }^{108}$

The Court had considered the matter, initially, against the background of confidential requests in relation to her testimony ${ }^{109}$ and protective measures,${ }^{110}$ both of which were filed on 29 July 2010.

At no stage did Mr Taylor's defence team, in its response, ${ }^{111}$ raise Article 19. The application was opposed only on grounds that it was unnecessary, ultra vires the Court's powers, 'imposed no sensible restriction which was not already covered'112 and that it was inappropriate because it sought to fetter the discretion of the Court to regulate its own proceedings.

The procedure adopted - despite the fact that the Court was sitting close to the source of ECtHR jurisprudence in Strasbourg and in the shadow of the UN's International Court of Justice in The Hague itself - is in sharp contra-distinction to the care taken by Tugendhat $\mathrm{J}$ in $R S T v U V W^{113}$ and Terry. ${ }^{114} \mathrm{He}$, as a reflex, considered issues that related to press and media Article 10 rights in the absence of representations by them because of the nature of the applications.

The SCSL found there were legitimate grounds for concern about Naomi Campbell's security and privacy 'by virtue of her public persona and the extremely intense media scrutiny relating to her anticipated testimony'. ${ }^{115}$ It ruled that, apart from the live feed from the courtroom of her testimony, the public, the media and

106. International Tribunals should respect freedom of speech issues. Article 19 of the 1948 UN Declaration of Universal Human Rights, states: 'Everyone has the right to freedom of opinion and expression; this right includes freedom to hold opinions without interference and to seek, receive and impart information and ideas through any media and regardless of frontiers.' 107. <http://www.bbc.co.uk/news/world-africa-10875811>.

108. The Presiding Judge was Justice Julia Sebutinde (Uganda). The other two were Justice Richard Lussick (Samoa) and Justice Teresa Doherty (Northern Ireland) who practised there and in Papua New Guinea. Lord Ken Macdonald (a former DPP, leading for Ms Campbell) and Courtney Griffiths QC (leading for Mr Taylor's defence team) failed to make any reference to freedom of speech issues. Given the circumstances, is it strange that Article 19 was ignored by both advocates and the judges.

109. SCSL-03-01-T-1018.

110. SCSL-03-01-T-1019.

111. SCSL-03-01-T-1027.

112. In the SCSL's Rules of Procedure and Evidence and the Code of Conduct, as amended, 13

May 2006.

113. [2009] EWHC $2448(\mathrm{QB})$ at [31-32].

114. [2010] EWHC 119 at [16-26] and [106-120].

115. SCSL-03-01-T at 5 . 
court staff 'shall not photograph, video record, or sketch Ms Campbell while entering ... exiting ... or while she is in the Tribunal building' without her leave or permission from the Court.

Ms Campbell and Princess Caroline of Monaco appear intent on having the last word - in Europe at least - on any matter relating to photography and privacy.

\section{CONCLUSIONS}

What is the future likely to bring for the development of seclusional and reputational privacy?

Von Hannover (2) and Max Mosley's Strasbourg references may clarify matters further and will - in themselves - be subject to the dynamic of interpretation and practical application in the United Kingdom. Strasbourg has the chance to revisit the whole seclusional issue of pictures of well-known people out and about in public and to consider the reputational and seclusional issues relating to the media's responsibilities in terms of prior notification.

Hugh Tomlinson $\mathrm{QC}^{116}$ saw four possibilities:

(1) Active steps could be taken to abrogate the new law.

(2) The current 'judge made' law of privacy could be replaced by a new 'statutory tort' of invasion of privacy.

(3) A special 'privacy regime' for the media could be established under a statutory regulator. ${ }^{117}$

(4) 'Steady as she goes' - the law of privacy could be left to develop in the current way by the judges on the basis of the Article 8 and Article 10 case law.

He concluded that: ${ }^{118}$

The law of privacy is slowly having an impact on the staple fare of the British tabloid reader. We are gradually moving from a position where anything could be published unless it was forbidden to the opposite - nothing about an identifiable individual can be published unless it can be justified. Under the influence of human rights case law from Strasbourg we are moving slowly but inescapably towards the stricter privacy protection of French or Italian law.

The General Election in May 2010 produced a Coalition Government which announced $^{119}$ a commitment to statutory changes in libel law for March 2011. Then Lord McNally, the Coalition Minister responsible for Human Rights and Civil Liberties, said the reform of libel law could also include issues in relation to the law of privacy. ${ }^{120}$

116. <http://inforrm.wordpress.com/2010/03/15/strasbourg-reputation-and-privacy-part-3-abalance-between-reputation-and-expression>, Introduction.

117. Something that may have moved a step closer: Express Newspapers Ltd's four national titles left the industry's self-regulatory body - the Press Complaints Commission (PCC) - in January 2011.

118. <http://inforrm.wordpress.com/2010/03/15/strasbourg-reputation-and-privacy-part-3-abalance-between-reputation-and-expression $>$.

119. <http://www.medialawyer.press.net/article.jsp?id=6928789>.

120. Liberal Democrats Conference 21 September 2010. 
Before the General Election, the House of Commons Culture, Media and Sport Committee took the view ${ }^{121}$ that, as the HRA had only been in force for nine years, it was inevitable the number of judgments involving freedom of expression and privacy was limited. The law relating to privacy would become clearer as more cases were decided. That might take 'some considerable time'. There was no unity among the press and media about the desirability of privacy legislation or how it might be drafted. The Committee concluded that matters relating to privacy should continue to be determined according to common law, with the flexibility that permitted, rather than set down in statute.

Further support for that view comes from a Reuters Institute for the Study of Journalism report. ${ }^{122}$ It found no evidence that the courts exercised a 'chilling' effect on responsible journalism in the public interest. ${ }^{123}$ There was, however, a 'challenge for newspapers and magazines who built a business model solely on infringing privacy through intrusive photographs or 'kiss-and-tell' revelations'.

The Reuters report recommended ${ }^{124}$ that media investigations had to be proportionate to what was being investigated and, also, be clearly targeted. It recognised ${ }^{125}$ that subterfuge and undercover techniques were sometimes necessary to reveal wrongdoing.

Comparing the OfCom Code with the PCC Code of Conduct in relation to respect for private life and media intrusion, the Report commended the two-stage OfCom process $^{126}$ (prima facie evidence that first justified the intrusion and secondly defended putting the material in the public domain). It described that approach as:

... clear, transparent and accountable .... the same rules should apply to print journalism. Newspapers may quarrel with that, not least because of differing views of what might constitute public interest in a celebrity culture and for commercial reasons. The hesitation is understandable but in a world that is much keener on transparency and accountability (and newspapers lead that charge) their own reluctance becomes less easy to defend.

All of this seems to be bringing together the elements of the Reynolds defence currently rooted in reputational privacy libel actions - to the point where it could be applied across the board to both reputational and seclusional privacy matters. That was the essence of the preparations made ahead of breaking the Jacqui Smith expenses story in the Sunday Express.

Case law could allow for the development of a proviso that failure to direct enquiries to the subject in question - along with relevant pictorial and documentary evidence to hand - would risk exposure to additional (or exemplary) damages at trial.

One of the problems of this approach - particularly in the tabloid market - is that the target of the enquiry may choose to frustrate everything and create a "controlled explosion' by confessing or revealing all to a rival publication to pre-empt the revelations and both manipulate and dilute the effect of them. Taking a pragmatic view, while some publications might benefit without putting in the time, cost and effort for such stories in the short term, the benefits would average out across the market in the medium to long term.

121. HC 3611 at [67].

122. S Whittle and G Cooper, Privacy, Probity and Public Interest, $2009<\mathrm{http}: / /$ reuters institute.politics.ox.ac.uk>.

123. Whittle and Cooper, Privacy, Probity and Public Interest, at 95.

124. Whittle and Cooper, at 96.

125. Whittle and Cooper, at 92.

126. Whittle and Cooper, at 96. 
Privacy actions themselves are clearly increasing. Nine of the privacy cases started in the High Court during the 12 months up to May 2010 involved celebrities ( 21 per cent of the total of 43 privacy cases). In 2009 only two (7 per cent of total of 28) involved celebrities. Equally significant is the fact that the bulk of privacy claims were not against the media: 22 claims (53 per cent) were brought against the public sector by people seeking protection from intrusion by the State. ${ }^{127}$

Finally, and counter-intuitively, current uncertainties in the law may inherently afford more practical privacy protection for media targets while - at the same time suiting the media.

That uncertainty creates a climate that favours early settlement - with lower costs on all sides - rather than the financial risks of full, set-piece trials which allow the media the opportunity to re-publish whatever is at issue under the protection of absolute privilege.

The Freddie Starr/Tabloid approach to privacy has clarified and developed the law in this area only because the foundations for that law existed in Article 8 (counterbalanced by Article 10) of the ECHR.

The United Kingdom Government took a major role in drafting the Convention. ${ }^{128}$ It was one of the original signatories. A less conservative (and more dynamic) approach by the judiciary and the legal profession - to reflect ECHR aims in UK domestic law during the 50 years before the HRA made its principles here mandatory - might have seen earlier clarification of all that is occurring now.

127. Media Lawyer 20 September 2010: <http://www.medialawyer.press.net/article.jsp?id= 7090373>.

128. David Maxwell Fyfe MP was the Deputy Nuremburg War Crimes Prosecutor and then Rapporteur for the drafting of the Convention - which had significant UK senior Civil Service input - and which was adopted in 1950, ratified by the UK Government in 1951 and which came into force in 1953. 